\title{
Avustralya Yönetsel Sistemi İçerisinde Yerel Yönetimler
}

$\ddot{O} z$

\author{
Zuhal ÖNEZ ÇETIN* \\ Onur KULAÇं
}

Avustralya Ulusu, 1901 yllında kurulmuş bir ülke olarak Commonwealth (federal), eyalet ya da bölge ve yerel düzeyden oluşan üç hükümet düzeyine sahiptir. Ayrıca, ülkede üç yönetim kolunu parlamento, yürütme hükümeti ve yargı kolları oluşturmaktadır. Çalışma kapsamında, Avustralya'nın siyasi ve idari yapısı, hükümet sistemi ve üç yönetim kolu çerçevesinde incelenecektir. İkincil olarak, Avustralya yönetsel sisteminde yerel yönetim sistemi öncelikli olarak yerel yönetimlerin sorumluluk alanları ve yasal mevzuat çerçevesinde açıklanacaktır. Ayrıca, çalışmada, yerel yönetimlerin gelirleri, personeli ve yerel yönetimlerde katılım konuları ayrı başlıklar çerçevesinde araştırma konusu edilecektir.

Anahtar Kelimeler: Avustralya, Yerel Yönetimler, Avustralya Hükümet Sistemi, Katılım

\section{Local Governments within the Australian Administrative System}

\begin{abstract}
The Australian Nation, as a country established in 1901, has three government levels composed of the Commonwealth (federal), state and territory, and local level. In addition, the parliament, executive government and the judiciary formed the three arms of government. Within the scope of the study, the political and administrative structure of Australia will be scrutinized within the framework of the government system and three administration branches. Secondly, in the Australian administrative system, the local administration system will be discussed primarily within the framework of local governments' areas of responsibility and legal legislation. Furthermore, in the study, the revenues of local governments, personnel of local governments and participation in local governments will be the focus of the research under different headings.
\end{abstract}

Keywords: Australia, Local Governments, Australia Government System, Participation

Geliş/Received: 24.02 .2021

Kabul/Accepted: 25.06 .2021

* Bu çalışma, insanlardan veri ve örnek toplamayı gerektiren, anket, inceleme, alan çalışması ve deney içeren araştırmalar kapsamına girmediğinden etik kurul onay belgesi gerektirmemektedir.

\footnotetext{
* Dr. Öğr. Üyesi, Uşak Üniversitesi, İİBF, Kamu Yönetimi Bölümü, zuhal.cetin@ usak.edu.tr ORCID ID: 0000-00024241-1487

† Dr. Öğr. Üyesi, Pamukkale Üniversitesi, İ̈BF, Siyaset Bilimi ve Kamu Yönetimi Bölümü, okulac@ @au.edu.tr ORCID ID: 0000-0002-5135-0356

(Makale Türü: Derleme Makalesi)
} 


\section{Giriş}

Avustralya, Pasifik Okyanusu ve Hint Okyanusları arasında konumlanan Dünyanın en büyük ülkelerinden ve aynı zamanda en büyük adalarından birisi olup doğusundaki en yakın komşusu Yeni Zelanda ve kuzeyindeki komşusu Papua Yeni Gine'dir (The Commonwealth, 2021). Avustralya yaklaşık olarak 7,69 milyon $\mathrm{km}^{2}$ 'lik bir alanı kapsamakta ve ülke Dünyanın en büyük altıncı ülkesi olarak yer almaktadır; nüfusu yaklaşık 25 milyondur ve nüfus ağırlıklı olarak ülkenin kıyı bölgelerinde yaşamaktadır (European Parliament, 2020: 1).

Buna ek olarak, 50.000 yıllık bir dönemden bu yana Aborjin ve Torres Boğazı Adalı halkları Avustralya topraklarında yaşamaktadır; 1700'lü yılların sonunda İngiliz Kolonileri kurulmuş ve 1800 'lü yılların bitimine gelindiğinde bu Koloniler kendi parlamentolarına sahip olmakla beraber İngiliz Parlamentosu'nun kanun yapma gücüne tabi durumda bulunmaktadırlar. 1890'lı y1llarda her koloniden temsilciler kongre olarak adlandırılan toplantılara katılım sağlamış ve gerçekleştirilen kongreler sürecinde Anayasa taslağı hazırlanması gerçekleşmiş ve referandumlar vasıtasıyla oylamaya sunulmuştur; Anayasa referandumlarda onaylanması gerçekleşmişse de Anayasanın İngiliz Parlamentosunca da kabul edilmesi gerekliliği yer almıştır (Parliamentary Education Office, 2021a). Avustralya Ulusu, 1 Ocak 1901 tarihinde k1smi olarak kendi kendini yöneten altı İngiliz Kolonisinin bir ulusun eyaletleri olmak adına birleşmesiyle kurulmaktadır ve bu ulusun hükümet kuralları Avustralya Anayasasında yer almaktadır; Anayasa ulusal hükümetin nasıl işleyeceğini ve hangi konularda yasalar çıkarabileceğini tanımlamaktadır (Australian Government, 2021). Avustralya, 1901 y1lında İngiliz Parlamentosu'nun alt1 Avustralya Kolonisi'nin kendilerini Avustralya Ulusu (Commonwealth of Australia) olarak yönetmelerine izin veren Anayasayı kabul etmesiyle birlikte bağımsız bir ulus haline gelmiştir (Australian Embassy, 2021: 6).

9 Temmuz 1900 tarihinde onaylanarak, 1 Ocak 1901 tarihinde yürürlüğe girmiş bulunan Avustralya Anayasası ilgili temel özellikler şu şekilde sıralanabilir: Anayasa federal bir sistem kurmaktadır ve bu federal sistemde ulusal hükümet ve eyaletler gücü paylaşmaktadır. Anayasa ulusal hükümetin yetkilerini tanımlar ve kalan yetkiler eyaletlerde yer almaktadır. Ulusal Hükümet Hukuku ve Eyalet Hukuku arasında tutarsızlık olması durumunda ulusal hükümet hukuku öncelikli yer almaktadır (Library of Congress, 2005: 15). Avustralya hükümet sistemine ilişkin şu özellikler sıralanabilir: Karma bir hükümet sistemine sahip bir ülke durumundadır; temsili demokrasi çerçevesinde Avustralya vatandaşları kendi adlarına yasa çıkarabilmeleri için parlamento üyeleri için oy kullanmaktadır. Anayasal monarşi kapsamında mutlak güce sahip olmamakla beraber Avustralya'nın devlet başkanı Kraliçe'dir ve Anayasaya uymak sorumluluğundadır ve son olarak, Eyaletler Federasyonu çerçevesinde bir Federasyon kanun 
yapma yetkilerinin bir kısmını ulusal hükümete vermiş bulunan bir grup eyaleti ifade etmektedir (Parliamentary Education Office, 2021b). Avustralya'da üç hükümet düzeyi yer almaktadır ve bu düzeyler; Commonwealth (federal), eyalet veya bölge ve yerel düzeydir. Avustralya Federal sistemi kapsamında hükümetin yetkileri federal ve eyalet hükümetleri arasında bölünmüş durumdadır. Avustralya'da bir federal parlamento mevcut olmakla birlikte altı adet eyalet ve iki adet bölge parlamentosu bulunmaktadır. Avustralya hükümetinde eyalet ve bölge hükümetlerince oluşturulan yerel düzey yer almaktadır; yargı sisteminde yer alan en yüksek mahkeme Avustralya Yüksek Mahkemesidir (European Parliament, 2020: 1). Bu doğrultuda, Avustralya hükümet sisteminin önemli özelliklerinden bir tanesi 'güçler ayrılığı' (Seperation of Powers) olarak belirtilmekte ve güçler ayrılı̆̆ kapsamında kanun yapma ve yönetme yetkisi mahkemeler, hükümet ve parlamento arasında paylaşılmaktadır (Parliamentary Education Office, 2021b).

Çalışmada, öncelikle Avustralya'da siyasi ve idari yapı; üç düzey hükümet sistemi ve parlamento, yürütme hükümeti ve yargı olmak üzere üç yönetim kolu üzerinden genel olarak açıklanacaktır. İkincil olarak, Avustralya yönetsel sistemi kapsamında yerel yönetimler yasal mevzuat, işlevleri ve hizmetleri açısından incelenecek ve 1995 tarihli Yerel Yönetimler Yasası çerçevesinde yerel yönetimlerin organları ve görevleri açıklanacaktır. Son olarak, yerel yönetimlerin gelirleri, yerel yönetimlerin personeli ve yerel yönetimlerde katılım konuları ele alınacaktır.

\section{Avustralya'da Siyasi ve İdari Yapı}

Avustralya'nın resmi adı 'Avustralya Ulusu/ Commonwealth of Australia' olmakla birlikte, ülke temsili bir demokrasidir ve aynı zamanda Avustralya'nın devlet başkanı olarak Kraliçe II. Elizabeth ile ülke anayasal bir monarşidir (Australian Government, 2021). Ayrıca, Avustralya federal bir devlet yapisına sahip bulunmakta ve bu federal devlet yapisı altı eyalet ve iki özerk bölgeden oluşmaktadır. İngiltere Kraliçesi devlet başkanı olmakla beraber Avustralya Genel Valisi ve altı eyalet Valisi vasıtasıyla yetkilerini kullanmaktadır (Dış Ekonomik İlişkiler Kurulu/ DEIK, 2014: 1). Avustralya'da altı eyalet ve iki bölge şu şekilde ifade edilmektedir: Avustralya'daki eyaletler; Victoria, Güney Avustralya, Bat1 Avustralya, Queensland, New South Wales, Tazmanya ve bölgeler ise Avustralya Başkent Bölgesi (Australian Capital Territory) ve Kuzey Bölgesi'dir (Northern Territory) (Avustralya Ülke Bülteni, 2018: 2).

Avustralya siyasi sistemi Westminster modeline göre işlemekte olan parlamenter bir demokrasi olmakla beraber, Westminster sisteminde Parlamentonun Alt Meclisindeki (Lower House of Parliament) çoğunluk hükümeti oluşturmakta ve başbakanı atamaktadır; başbakan alt meclise karş1 sorumlu olan kabineyi seçmektedir (Library of Congress, 2005: 15).

Avustralya hükümeti İngiliz geleneği, Westminster modelini izlemesi çerçevesinde, Genel Vali (Governor-General) Tacı temsil etmekte ve ulusun en yüksek yürütme gücünü 
kullanma sorumluluğuna sahiptir ve Hükümet başkanı, Başbakan ve diğer bakanların tavsiyesiyle görevlerini yerine getirmektedir. Başbakan ise Bakanlar Kurulunu (Cabinet of Ministers) yönetmekte ve her bir Bakan hükümet görevleri portföyünden sorumlu bulunmaktadır. Avustralya Ulusu'nun bakanlarının ve Başbakanın atanmasındaki işleyişe bakıldığında, Genel Vali tarafından federal parlamentodaki Temsilciler Meclisinin çoğunluğunu temsil eden bir siyasi parti ya da koalisyon liderinin tavsiyesi üzerine atanmaktadır (Australian Government Department of Foreign Affairs and Trade, 2016: 17). Genel Vali'nin ataması Başbakan'ın tavsiye üzerine Kraliçe tarafından gerçekleştirilmekte ve anayasal ve yasal görevler, resmî törensel görevler ve törensel olmayan sosyal görevler olmak üzere üç kategoride işlev alanları mevcut bulunmaktadır (Parliament of Australia, 2021a). Bu kapsamda, Genel Vali başbakanın tavsiyesi üzerine Kabine'nin atamasını gerçekleştirmektedir. Kabine üyelerinin hepsi parlamento üyesi olmak durumundadır ve ulusal hükümetin altı eyaleti arasında Parlamento üyeleri şu şekilde dağıtılmaktadır: Yeni Güney Galler (New South Wales) 48 üye, Victoria 37 üye, Queensland 30 üye, Güney Avustralya (South Australia) 11 üye, Batı Avustralya (Western Australia) 15 üye, Tazmanya beş üye ve diğer iki bölge olan ACT ve Kuzey Bölgesi (the Northern Territory) ikişer üye bulunmaktadır (CLGF, 2017-2018: 5).

Ayrıca, Avustralya'da Federal Parlamento'nun iki kanadı bulunmaktadır; bunlardan ilki olan Temsilciler Meclisi'nin 150 üyesi mevcut bulunmakta ve Temsilciler Meclisi seçimleri üç yılda bir gerçekleşmektedir. Parlamento'nun ikinci kanadı olan Senato'nun ise 76 üyesi bulunmakta olup bu üyeler içerisinde eyaletlerin 12 temsilcisi ve bölgelerin ikişer temsilcisi bulunmaktadır (Avustralya Ülke Bülteni, 2018: 2).

Buna ek olarak, Avustralya'da üç yönetim düzeyi ya da kademesi şu şekilde ifade edilmektedir: Tüm ülke (The Whole Nation), eyalet veya bölge (State or Territory) ve yerel alan (City, Municipality, Shire)' dan oluşmaktadır. Tüm ülkeye ilişkin lider ve yürütme organı başbakan ve federal parlamentodur, federal parlamento 150 üyeye sahip bulunan Temsilciler Meclisi (House of Representatives) ve 76 üyeli Senatodan oluşmaktadır. İkinci olarak 6 eyalet ve 2 bölge, lider ve yürütme organı bölgelerdeki başbakan ve NSW Parlamentosudur; 93 üyeli Yasama Kurulu (Legislative Assembly) ve 42 üyeli Yasama Meclisi'nden (Legislative Council) oluşmaktadır. Üçüncü olarak, yerel alan (Local Area) Avustralya'da sayısal olarak 560’tan fazla ve 152 NSW'da bulunmaktadır, lider ve yürütme organı belediye başkanı (Lord Mayor), kent, belediye veya Shire Meclisinden oluşmaktadır (Parliament of New South Wales, 2021: 3). Federal hükümet posta, telefon, internet, para, göçmenlik, savunma gibi ulusal konulardan; eyalet ve bölge hükümetleri o eyalet veya bölgedeki insanları etkilemekte olan okullar, toplu taşıma, hastaneler, toplu konut gibi konulardan; yerel meclisler yerel toplulukları etkileyen otopark, çöp 
toplama ve geri dönüştürme, parklar, spor sahaları ve yüzme havuzları gibi konulardan sorumlu bulunmaktadır (Parliamentary Education Office, 2021c).

Avustralya üç düzeyde hükümete sahip olmakla birlikte bu düzeyler kanun yapma yetkilerine sahiptir ve bunlar Federal ya da ulusal parlamento; eyalet/bölge parlamentoları ve yerel meclislerdir. Federal, eyalet ve Kuzey Bölgesi ve ACT hükümetlerinin üç kolu şu şekilde ifade edilmektedir: "Yasama organı ya da parlamento çıkarılacak yeni yasaların tartışlması ve oylanmasından sorumludur; yasaları çıkartmaktan ve yasaları uygulamaktan sorumlu bulunan bir Yürütücü; diğer şeylerin yanı sira bu tür yasaların uygulanmasindan sorumlu bulunan bir Yargl" dır (Australian Government Australian Trade Commission, 2016: 2). Ayrıca, Avustralya Anayasası'nda federal ve eyalet hükümetleri arasındaki yetki paylaşımı düzenleme konusu edilmektedir. Her bir eyaletin kendine ait Anayasası bulunmakta ve kendi Anayasaları eyaletin kanun yapma yetkilerini belirlemektedir. Federal Parlamento'nun kanun çıkarabileceği alanlar Avustralya Anayasası'nın 51 ve 52. Bölümlerinde liste olarak açıklanmaktadır (Australian Government Australian Trade Commission, 2016: 3). Ayrıca, Eyalet parlamentolarının Anayasa tarafindan federal Parlamentoya tahsis edilmeyen herhangi bir konuda kanun yapma yetkisi bulunmakta ve eyalet kanunları genelde yerel yönetimler, eğitim ve okullar, sağlık, çevrenin bazı yönleri, acil service operasyonu (polis, itfaiye ve ambulans) gibi konuları kapsamaktadır (Australian Government Australian Trade Commission, 2016: 4).

\section{Avustralya'da Üç Yönetim Kolu}

Avustralya Parlamentosu Kraliçe, Senato ve Temsilciler Meclisinden oluşmakta ve ülkeyi etkileyen kanunların çıkarılması Parlamentonun sorumluluğundadır (Australian Government, 2021). Avustralya Anayasas1, Federal Hükümeti; Parlamento, Yürütme Hükümeti ve Yargı olarak kurmaktadır ve bu yapı 'hükümetin üç kolu' olarak da isimlendirilmektedir (Parliament of Australia House of Representatives, 2019: 1). Avustralya'da hükümetin üç kolu şu şekilde suralanmaktadır (Australian Government, 2021):

1) Yasama organı (ya da parlamento) Anayasanın 51. Maddesinin yetkisi kapsamında çıkarılacak olan yeni yasaların tartışılması ve yeni yasaların oylanmasından sorumlu bulunmaktadır,

2) Yürütme (Avustralya Hükümeti) yasama organınca oluşturulan yasaların yürürlüğe koyulması ve bu yasaların uygulanmasından sorumlu bulunmaktadır; yasama organının belirli üyeleri bakanlar olarak isimlendirilir, yürütmenin üyeleridir ve Bakanlar yasanın belirli alanlarında özel sorumluluklara sahiptir, 
3) Yarg1, federal hükümetin yasal kolu olmakla beraber, diğer iki koldan bağımsız bulunmaktadır; yargı sorumluluk olarak yasaların uygulanmasından ve diğer iki kolun kendi yetkileri kapsamında hareket edip etmediğine dair karar verme sorumluluğu bulunmaktadır.

Çalışma kapsamında, Avustralya'da hükümetin üç kolu Parlamento, Yürütme Hükümeti ve Yargı başlıkları çerçevesinde ayrıntılı olarak açıklanacaktır.

a) Parlamento: Anayasa yasama yetkisini, yasa yapma yetkisini, Parlamentoya vermektedir. Parlamento'nun oluşumuna bakıldığında, Parlamento Genel Vali tarafindan temsil edilen Kraliçe ve İki Meclis yani Temsilciler Meclisi ve Senato'dan oluşmaktadır (Parliament of Australia House of Representatives, 2019: 1).

Anayasa; Kraliçe, Temsilciler Meclisi ve Senato'dan oluşan Commonwealth Parlamentosu'nu kurmaktadır (Anayasa 1-60 bölümleri) ve altı eyaletin her birinin halkı aynı sayıda Senatör seçmektedir. Kuzey Bölgesi ve Avustralya Başkent Bölgesi halkının her biri iki senatör tarafindan temsil edilmektedir (Commonwealth of Australia, 2010: V). Avustralya parlamentosunun dört temel işlevi şu şekilde ifade edilmektedir: İlk olarak kanun yapma yetkisi bulunmaktadır ve Avustralya halkı adına ulusal kanunlar yapmaktadır. İkinci olarak temsil yetkisi mevcuttur, Parlamento Avustralya vatandaşlarının, partilerinin ve diğer grupların çıkarlarını ve görüşlerini temsil fonksiyonu bulunmaktadır. Üçüncü olarak hükümeti oluşturma işlevi yer almaktadır. Parlamento, federal bir seçimin ardından Temsilciler Meclisi'nde çoğunluğu elde eden partiden hükümeti oluşturmaktadır. Son olarak, Parlamentonun inceleme fonksiyonu bulunmaktadır ve Parlamento, yürütme hükümetinin çalışmalarını denetlemektedir (Constitutional Centre of Western Australia, 2019: 2).

Parlamento'nun yaptığı işler özetle şu şekilde belirtilmektedir: Parlamento yasayı geçirmekte; Parlamento Yürütme Hükümetine harcama ve vergilendirme için hükümetin önerilerini kabul ederek kamu parasını harcama yetkisi vermekte; hükümetin idari işlemlerini incelemekte, kamu politikası tartışması için bir forum görevini yerine getirmektedir (Parliament of Australia House of Representatives, 2019: 1-2).

Parlamento'nun yaptığı çalışmalar, dört Parlamento Departmanı personelince desteklenmektedir. Bu ilgili birimler Senato Departmanı (Department of Senate), Temsilciler Meclisi Departmanı (Department of House of Representatives), Parlamento Hizmetleri Departmanı (Department of Parliamentray Services) ve Parlamento Bütçe Ofisi'dir (Parliamentary Budget Office) (Parliament of Australia, 2021b).

b) Yürütme Hükümeti: Anayasa, Commonwealth'in yürütme gücünün Kraliçe'ye ait olduğu ve aynı zamanda Kraliçe'nin temsilcisi olarak da Genel Vali tarafından kullanılabileceği belirtilmektedir. Yürütme Hükümeti’nin pratikteki görünümüne bakıldığında, yürütme yetkisi Başbakan ve Kabine tarafından sahiplenilmiştir. Güçleri anayasal olarak Federal Yürütme 
Konseyi üyeliğinden ve Genel Valiye danışman statüsünden; siyasi olaraksa Temsilciler Meclisi seçimlerinde halktan ve son olarak gelenekten; yani gelenek ve görenekten kaynaklı olduğu ifade edilmektedir (Parliament of Australia House of Representatives, 2019: 2).

Kabine, Avustralya Hükümetinde en üst karar alma grubu olarak Başbakan ve Yürütme Hükümeti'nin bir parçası niteliğinde yaklaşı 19 bakanı kapsamakta ve Kabine bakanları büyük devlet dairelerinin sorumluluğunu üstlenmektedir. Kabine'nin rolü hükümet politikasını yönlendirmek ve ulusal meseleler hakkında karar vermek olarak belirtilmektedir. Kabine toplantılarında bakanlar kendi devlet dairelerince hazırlanmış bulunan yasa tasarılarını sunmakta, Kabine bu tasarıları değerlendirmekte ve bakanlara kanun tasarılarının Meclise getirilip getirilmeyeceği ya da değişiklik yapılmasını önermektedir (Parliamentary Education Office, 2021d).

Başbakan, Anayasa uyarınca Genel Vali tarafından atanmakta ve Genel Vali Temsilciler Meclisi'nde çoğunluğa sahip olan partinin parlamento liderini veya koalisyon partilerini atamaktadır. Başlıca işlevleri bakanlık tavsiyesi almak ve ilanlar, yönetmelikler, kararnameler ve yasal atamalar gibi resmî belgelerin imzalanmasını onaylamak olan Federal Yürütme Konseyi (The Federal Executive Council), Genel Vali'nin başkanlık yaptığı bütün bakanlardan oluşmaktadır. Avustralya, bir Kabine sistemi altında çalışmaktadır, Kabine Anayasa'da belirtilmemekte ancak hükümetin önemli karar alma organı durumunda olup Kabine üst düzey Hükümet Bakanlarından oluşmakta ve Kabine'nin aldığı kararlar, Federal Yürütme Konseyi tarafından resmi şekilde onaylanarak yasal geçerlilik kazanmaktadır (Parliament of Australia, 2021a). Buna ek olarak, Başbakan her soru zamanında meclise gelmekte ve hükümet politikası hakkında önemli açıklamalarda bulunmaktadır (Parliament of Australia House of Representatives, 2020: 3).

Bakanlık oluşumunda Başbakan, Kabine, Bakanlar ve Parlamento Sekreterleri yer almaktadır. Başbakan hükümetin başıdır ve başbakan bu konumuna hükümette partinin seçilmiş lideri olarak erişmektedir ve Kabine'ye başbakan başkanlık etmekte ve Kabine kıdemli bakanlardan oluşmaktadır. Ana politika ve yasa tekliflerine Bakanlar Kurulu tarafından karar verilmekte ve Başbakan Kabine pozisyonları için Bakanları seçmekle sorumlu bulunmaktadır. Başbakan bakanları seçmektedir; Bakanlar her iki Parlamento Meclisinden atanmakla beraber yaklaşık olarak Bakanların üçte ikisi Temsilciler Meclisi Üyesidir. Sayısal olarak en çok 12 üye ve Senatör, idari sorumluklarına ilişkin olarak Bakanlara yardımcı olabilmek adına veya Bakanları temsil etmek için Parlamento Sekreteri olarak Başbakan tarafından atanmaktadır (Parliament of Australia House of Representatives, 2019: 2). Parlamentoda kendi departmanlarıyla ilgili konularda hükümetin sözcüsü olarak hareket eden Bakanların görevleri şu şekilde ifade edilmektedir: Mevzuatın uygulanmasını sağlamak ve yönetmek, hükümet politikası 
ile alakalı olarak açıklamalar yapmak ve idari sorumluluklarına ilişkin soruları yanıtlamak (Parliament of Australia House of Representatives, 2020: 3).

c. Yargı: Anayasa, Commonwealth' in yargı yetkisine şu gibi yetkiler vermektedir: Kanunları yorumlamak ve Yüksek Mahkeme ve diğer federal mahkemelerdeki münferit (bireysel) davalarda geçerli olup olmadığına karar vermek. Anayasa ile Yüksek Mahkeme oluşturulmakta ve Parlamento mevzuatıyla diğer federal mahkemeler kurulmaktadır (Parliament of Australia House of Representatives, 2019: 4).

Avustralya Anayasası, Avustralya Yüksek Mahkemesinin oluşturulması öngörmekte ve Anayasa Parlamento'nun oluşturabileceği diğer mahkemelerin kurulmasını mümkün kılmaktadır. Yüksek Mahkeme yargıçlarının ataması Konsey'deki Genel Vali tarafından gerçekleştirilmektedir (Parliament of Australia, 2021a).

\section{Avustralya Yerel Yönetim Sistemi}

Avustralya'da tüm yönetim alanlarının dışında yerel yönetimler topluluklarla en yakın ilişki içerisinde bulunmakta olup yerel ve topluluk ihtiyaçlarının karşılanması ve anlaşılması gibi konularda önemli bir avantaja sahiptir. Yerel yönetim sistemleri eyaletler arasında farklilık göstermektedir ancak yerel yönetimler genel olarak yönetişim, hizmet sunumu, savunuculuk (advocacy), varlık yönetimi, planlama, topluluk gelişimi ve düzenleme rollerine sahip bulunmaktadır (Australian Government Department of Infrastructure, Transport, Regional Development and Local Government, 2007-2008: 2).

Avustralya Ulusal Anayasası yerel yönetimlere ilişkin atıfta bulunmamakla beraber, yerel yönetimler Avustralya'da tüm eyalet anayasaları çerçevesinde ve Kuzey Bölgesi'nin Anayasası olan federal mevzuatta tanınmaktadır. Yerel yönetimler üzerinde federal bir yargı yetkisi söz konusu bulunmazken, her eyalet ya da bölgenin kendine ait yerel yönetim mevzuatı bulunmaktadır (CLGF, 2017-2018: 5).

Yerel yönetimlerin hizmet sunumu ve yerel yasa yapabilme konusundaki gücünün kaynağı Eyalet Parlamentosundan (State Parliament) geçen mevzuattan kaynaklanmaktadır ve yerel yönetimlere güç kazandıran ve yerel yönetimler için en önemli yasalardan biri 1995 tarihli Yerel Yönetimler Yasası'dır. Söz konusu yasa, şu sıralanan özellikleri içermektedir "yerel yönetimlerin işlevlerini, seçimlerin nasıl yapılması gerektiğini açıklar ve işlerinin incelenmesi de dahil olmak üzere yerel yönetimlerin yönetim ve finansal yönetimi için bir çerçeve oluşturur" (Government of Western Australia, 2019: 2). 1995 tarihli Yerel Yönetim Yasası ile Bat1 Avustralya'da yer alan yerel yönetimler bölgelerinin iyi bir şekilde yönetilebilmesi için gerekli olarak görülen yerel yasaları yapabilme imkânı kazanmıştır (Department of Local Government, Sport and Cultural Industries, 2021a). 
Yerel yönetimler ilgili Kanuna ek olarak yetki elde edebildiği farklı birçok kanun yer almaktadır. Bu kanunlar içerisinde önemli olanlardan birisi 2016 tarihli Halk Sağlığı Yasası (The Public Health Act) olup yerel yönetimlere her bir topluluğun sağlığını korumak adına geniş içerikli yetkiler sağlamaktadır. Ayrıca, 2005 tarihli Planlama ve Kalkınma Yasası (The Planning and Development Act) da yerel yönetimlere yerel planlama programları hazırlama ve düzenli gelişimini sağlama konularında yetki vermektedir (Government of Western Australia, 2019: 2).

Yerel yönetim alanları, boyut ve karakter yönlerinden değerlendirildiğinde farklılıklar bulunmaktadır; bu kapsamda Sidney Bölgesi yaklaşık olarak 35 şehir, belediye ya da belediye meclislerine (Shire Councils) ayrılmış; Bathurst ve Albury daha büyük ülke merkezlerindeyse kent ya da belediye meclisleri bulunmaktadır (Parliament of New South Wales, 2021: 4). Yerel yönetimlerin gücü Yerel Yönetim Kanunları gibi Eyalet Parlamentosu Kanunları tarafından kontrolü gerçekleşmektedir. Yerel Meclisler (Local Councils)'in sorumlu olduğu konular şu şekilde sıralanmaktadır: Bina düzenlemeleri ve imar, halk sağlığı, yerel yollar ve patikalar, parklar ve oyun alanları, kütüphaneler, yerel çevre konuları, atık bertarafı ve birçok toplum hizmeti (Parliament of New South Wales, 2021: 4).

Yerel yönetimlerin geleneksel odak noktası alt yap1 ve belediye hizmetleri üzerine olmakla birlikte, son 50 yıllık dönemde yerel yönetimlerin boyutu, kapsamı ve rolünde bir artış durumu söz konusu bulunmaktadır; yerel yönetimler altyapı hizmetlerinin yanı sıra vatandaşa yönelik hizmetlere daha fazla dâhil olmaktadır (Australian Local Government Association, 2021 a: 1). Bu kapsamda, Meclisler hizmet sunumunu yerel ihtiyaçlara göre ve ayrıca çeşitli Eyalet yerel yönetim kanunlarının gerekliliklerine göre tespit etmektedir, yerel yönetim işlev ve hizmetleri şu şekilde belirtilebilir (Australian Government Department of Infrastructure, Transport, Regional Development and Local Government, 2007-2008: 2-3): “İdare (hava alanlar1, taş ocakları, mezarlıklar, park istasyonları ve cadde park yerleri), bina (denetim, ruhsatlandırma, sertifikasyon ve uygulama), toplum hizmetleri (çocuk bakımı, yaşlı bakımı ve barınma, sığınma tesisleri, tekerlekler üzerinde yemekler, danışmanlık ve refah), kültürel/ eğitim (kütüphaneler, sanat galerileri ve müzeler), mühendislik (bayındırlık işleri tasarımı, yolların, köprülerin, patikaların yapımı ve bakımı, drenaj, temizleme, atık toplama ve yönetimi), sağlık (su numunesi alma, yiyecek numunesi alma, aşılama, tuvaletler, gürültü kontrolü, et denetimi ve hayvan kontrolü), planlama ve geliştirme onayı, rekreasyon (golf sahaları, yüzme havuzları, spor sahaları, rekreasyon merkezleri, salonlar, büfeler, kamp alanları ve karavan parkları), su ve kanalizasyon (bazı eyaletlerde), diğer (mezbahalar, satış yerleri, marketler ve grup satın alma planları)".

Yerel yönetimin yetki alanları içinde ve arasında önemli derecede farklılıklar olabilmekte, bu farkl11ık kırsal-metropolitan farkl1lıkların ötesinde yer almaktadır. Meclisler arasında büyüklük ve nüfus farklılıkların dışındaki diğer önemli farklılıklar şöyle ifade 
edilmektedir: "Yerel toplulukların tutumları ve istekleri, mali durum (gelir artırma kapasitesi dâhil), kaynaklar ve beceri tabanı, örneğin oy hakları ve seçim sistemleri dâhil olmak üzere yasal çerçeveler, fiziksel, ekonomik, sosyal ve kültürel çevreler, fonksiyonların aralığı ve ölçeği” (Australian Government, 2014-2015: 2).

Avustralya' da genel olarak Meclisler olarak isimlendirilmekte olan yerel yönetim alanları için anayasal sorumluluk sekiz eyalet ve bölge hükümetine ait bulunmakta ve bunlardan her biri kendi yerel yönetim sistemini yönetmektedir. Yerel yönetim sistemlerinin her birinin mevzuat1 bulunmakta ve mevzuatlarında yerel yönetimlerin yerel seçim hükümlerini ve yerel yönetim yetki ve sorumluklarına ilişkin açıklamalar yer almaktadır. Sekiz eyalet ve bölgeden yedi tanesinin ayrı bir yerel yönetim kademesi mevcut olmakla birlikte, bölge hükümetinin tüm yerel yönetim işlevlerini yerine getirdiği ACT istisnai durumda bulunmaktadır (CLGF, 2017-2018: 6).

Bu kapsamda, 1995 tarihli Yerel Yönetim Yasasına göre, yerel yönetimler bölgelerinde genel güce sahip bulunmakta ve bu genel güce bölgelerindeki insanların iyi yönetimini sağlamak adına sahip bulunmaktadır, bu da yasanın veya başka herhangi bir yazılı yasanın engellemediği takdirde yerel yönetimlerin karar alabilmesi anlamına gelmektedir. Yerel yönetimler yasama işlevi olarak yerel yasalar çıkarabildiği gibi yürütme fonksiyonu olarak da hizmet sunabilmektedir (Government of Western Australia, 2019: 2). Yerel yönetimlerin çıkarabileceği yerel yasalar şu şekilde sıralanmaktadır; "sağlık ve güvenlik, sokak ticareti, rezervler ve kıyı şeridi, işaretler, park yerleri, kediler ve köpekler" (Department of Local Goverment, Sport and Cultural Industries, 2021b).

\section{Yerel Yönetimlerin Organları ve Görevleri}

1995 tarihli Yerel Yönetimler Yasası'nın 'Yerel Yönetimler ve Yerel Yönetim Meclisleri' başlıklı ikinci bölümünde, 2.5. maddesinde yerel yönetimlere ilişkin şu açıklamalar yer almaktadır: "Kurumsal kurumlar olarak oluşturulan yerel yönetimler; (1) Eyaletin bir alanı bölge haline geldiğinde, bu bölge için bir yerel yönetim kurulur” (Western Australia Local Government Act, 1995: 14).

Ayrıca, "Seçilmiş meclisler tarafından yönetilecek yerel yönetimler" isimli 2.6. maddesinde şu açıklamalar yer almaktadır (Western Australia Local Government Act, 1995: 14$15)$ :

(1) Her yerel yönetim, yönetim organı olarak seçilmiş bir meclise sahip olacaktır,

(2) Bir şehir veya kasabanın yerel yönetim meclisindeki makamlar, belediye başkanı, belediye başkan yardımcısı ve meclis üyelerine aittir,

(3) Bir eyaletin (Shire) yerel yönetim meclisindeki makamlar, başkan, başkan yardımcısı ve meclis üyeleridir, 
(4) Vali, meclis üyelerinin görevleri ilk kez dolana ve meclis ilk toplantısını yapana kadar, bir mahalli idare komiseri olarak bir kişiyi emirle atayabilir.

Yerel Yönetimler Yasası'nın 'Meclisin Rolü’ başlıklı 2.7. maddesinde şu ifadeler yer almaktadır (Western Australia Local Government Act, 1995: 15):

(1) Meclis- (a) yerel yönetimin işlerini yönetir;

(b) yerel yönetimin işlevlerinin yerine getirilmesinden sorumludur,

(2) Altbölüm (1)'i sınırlamadan, meclis:

(a) yerel yönetimin maliyesinin ve kaynaklarının tahsisini denetler ve,

(b) yerel yönetimin politikalarını belirler.

Yerel Yönetimler Yasası'nın 'Belediye Başkanı veya Başkanın Rolü’ başlıklı 2.8. maddesinde şu açıklamalar yer almaktadır (Western Australia Local Government Act, 1995: 15):

(1) Belediye başkanı veya başkan - (a) bu Kanuna uygun olarak toplantılara başkanlık eder,

(b) bölgedeki topluluğa liderlik ve rehberlik sağlar,

(c) yerel yönetim adına yurttaşlık ve törenle ilgili görevleri yerine getirir,

(d) yerel yönetim adına konuşur,

(e) belediye başkanına veya başkana bu Kanun veya başka herhangi bir yazılı kanunla verilen diğer görevleri yerine getirir,

(f) yerel yönetimin işleri ve görevlerinin yerine getirilmesi konusunda CEO ile irtibat kurar.

Yerel Yönetimler Yasası'nın 'Meclis Üyelerinin Rolü' başlıklı 2.10 maddesinde, şu ifadeler yer almaktadır (Western Australia Local Government Act, 1995: 16):

Bir meclis üyesi (a) seçmenlerin, vergi mükelleflerinin ve bölge sakinlerinin çıkarlarını temsil eder, (b) bölgedeki topluluğa liderlik ve rehberlik sağlar, (c) topluluk ve meclis arasındaki iletişimi kolaylaştırır, (d) meclis ve komite toplantılarında yerel yönetimin karar alma süreçlerine katılır, (e) bu Yasa veya diğer herhangi bir yazılı yasa ile bir meclis üyesine verilen diğer işlevleri yerine getirir.

Ayrıca, Avustralya'da hem eyaletlerin kendi aralarında hem de eyaletlerin kendi içlerinde farklı meclis yapıları mevcuttur ve meclislerin kendi organizasyon yapıları ve komite sistemlerine ilişkin önemli takdir yetkileri bulunmaktadır; resmi meclis işlerini büyük ölçüde açık oturumda yürütmeleri gerekmektedir (CLGF, 2017-2018: 6).

\section{Yerel Yönetimlerin Gelirleri}

Yerel yönetimler kendi gelirlerini ücretler, harçlar ve tek vergi geliri olan oranlar yolu ile arttırmaktadır. Son on yılda Avustralya'nın toplam vergi gelirini yaklaşık olarak \%3'ünü yerel yönetimler arttırmıştır. Yerel yönetimler gelirinin \%80'nini sağlamaktadır ve Avustralya 
Hükümeti tarafından sağlanan finansman yerel yönetimler için önemli bir gelir kaynağıdır ve özellikle de bölgesel ve uzak topluluklar için ilgili finansman önemli bir gelir kaynağını oluşturur (Australian Local Government Association, 2021b: 1).

$\mathrm{Bu}$ kapsamda, yerel yönetimlerin gelirleri şu şekilde ifade edilmektedir (Government of Western Australia, 2019: 3-4):

a) Oranlar (Rates): Oranlar mülk üzerindeki bir vergiyi ifade etmektedir ve Avustralya'da birçok yerel yönetim için temel gelir kaynaklarından birini oluşturmaktadır. 1995 Yerel Yönetim Yasası ve 1978 Arazi Değerleme Yasası, mülkün oranlanabilir değerini ve alınabilecek oran türlerini değerlendirme konusu yapabilmek adına yöntemler belirlemektedir ve sonrasında her yerel yönetim alınması gerekli oranın türünü ve miktarını tespit etmektedir,

b) Borçlanma (Borrowings): Yerel yönetimler borç para alabilmektedirler, normal oranların ve diğer gelir kaynaklarının yeterli olmadığı durumlarda yerel yönetimler büyük ölçekli sermaye faaliyetlerine başlamak için kredi alabilmeleri mümkündür,

c) Harçlar ve Ücretler (Fees and Charges): Birçok yerel yönetim gelirlerinin küçük bir yüzdesini ücretlerden ve harçlardan alabilmektedir, yerel yönetimlerin ücret ve harç uygulayabileceği durumlar da şu şekilde ifade edilmektedir: "Yerel yönetim tarafından sahip olunan, yönetilen veya bakımı yapılan tesislerin kullanımı veya kabul edilmesi, bir kişinin isteği üzerine hizmet veya iş temini, malların temini, kayıtlardan bilgi sağlanması, bir ruhsat veya iznin onaylanması, incelenmesi veya verilmesi için bir başvuru alınması",

d) Ticari İşletmeler (Commercial enterprises): Gelir elde etmek amaciyla yerel yönetimlerin, ticari işletmelere dahil olma kapsamı bulunmaktadır.

Avustralya'da 2014-15 döneminde, meclisler kendilerine ait gelirlerini yüzde 89,7'sini arttırmıştır, geri kalan yüzde 10,3'ü hibe ve sübvansiyonlar oluşturmaktadır (Australian Government, 2014-2015: 4). Buna ek olarak, yerel yönetimlerin vergileri arttırma konusundaki diğer bir yolu mülk üzerindeki oranlar olarak belirtilmekte, 2014-15 döneminde, yerel yönetim gelirlerinin yüzde 38,2' si ulusal olarak oranlardan elde edilmiş bulunmaktadır ve ortalama olarak, yerel yönetimler 2014-2015 döneminde gelirlerinin \%27,1'ini mal ve hizmetlerin satışından elde ettiği ifade edilmektedir (Australian Government, 2014-2015: 5).

Bu kapsamda, yerel yönetim harcamalarında konut ve toplum hizmetleri \%23,8'lik orana, ulaşım ve iletişim \%22,5 orana ve genel kamu hizmetleri \%17,2 orana sahip bulunmaktadır (Australian Government, 2014-2015: 6). Avustralya Yerel Yönetim Derneği (Australian Local Government Association, 2021c), yerel yönetimlerle ilgili bazı veri ve rakamları şu şekilde ifade etmektedir: “2018-2019'de yerel yönetim ücret (oran)'lerde \$18,9 milyar dolar topladl. Yerel yönetim oranlarl, tüm yönetim kademeleri tarafindan toplanan verginin sadece \%3,4'ünü oluşturur ve yerel yönetim tarafindan alınan tek vergidir. Yerel yönetimin toplam yıllık harcaması 
\$38,8 milyar dolardır (2018-19)". Buna ek olarak, Avustralya'da sektörün başlıca harcama kalemlerini Avustralya Yerel Yönetim Derneği (Australian Local Government Association, 2021c) şu şekilde belirtmektedir: "Ulaşım $(\% 22,4)$ ve rekreasyon, kültür ve din $(\% 16,6)$ ve çevrenin korunması $(\% 14,8)$ (2018-19); Binalar ve yapılar, makine ve teçhizat ve arazi dahil olmak üzere yerel yönetim finansal olmayan varlıklarının yenileme maliyeti $\$ 457$ milyar dolardir (2018-19)".

Ayrıca, Yılmaz (2021: 107-108) ‘Avustralya'da Yerel Yönetimlerin İdari ve Mali Yapısı’ isimli çalışmasında toplam kamu harcamalarının yüzdesi olarak yerel yönetim harcamaları 20092019 (milyon \$) başlığı ile Avustralya İstatistik Bürosu, IMF ve OECD verilerinden faydalanarak bir tablo oluşturmuş ve ilgili tabloya göre toplam kamu harcamaları kapsamında yerel yönetim harcamalarının payının yıllık olarak ortalama yüzde 5 ile 6 arasında değişim gösterdiğini ve 20092019 yılları kapsamında yerel yönetimlerin toplam kamu kesimi harcamalarının yaklaşık olarak yüzde 5,5'ini karşılamakta olduğunu belirtmektedir.

Mali Yardım Hibe Programı (The Financial Assistance Grant Program), Avustralya Hükümeti'nden Avustralya'daki Yerel Yönetimlere Eyalet Hükümetleri aracıllğıyla finansman sağlar, finansman desteğini Eyaletin hibe komisyonunun tavsiyesi üzerine gerçekleştirmektedir. Her bir yerel yönetim Yerel Yönetim (Mali Yardım) Yasası 1995 Ulusal İlke gerekliliklerine uygun bir şekilde genel amaçlı finansman havuzunun \%30'unun kişi başına dağılımına eşdeğer asgari bir hibe alabilme imkânına sahiptir. Fonlar yatay bir mali eşitleme (fiscal equalisation) temelinde sağlanmaktadır, bu şekilde sağlanmasıyla bir eyalette yer alan yerel yönetimlerin hepsi birbirine benzer bir hizmet çeşitliliği ve benzer kalitede hizmet sağlayabilme becerisine erişebilmektedir (Australian Government Productivity Commission, 2017: 11-12).

Avustralya Hükümeti, yerel yönetimlere Mali Yardım Hibe Programı çerçevesinde 197475 döneminden bu yana sağladığı kaynak $\$ 58$ milyar dolardan fazla bulunmaktadır ve hibenin sağlanması 1995 Yerel Yönetim (Mali Yardım) Yasası kapsamında gerçekleşmektedir. Mali Yardım Hibe Programı iki bileşenden meydana gelmektedir. Bu bileşenlerden birincisi nüfusa göre eyaletler ve bölgeler arasında dağıtılan genel amaçlı bir bileşendir. İkinci bileşen ise sabit tarihsel paylara göre eyaletler ve bölgeler arasında dağıtılan tanımlanmış bir yerel yol bileşeni olarak ifade edilmektedir (Australian Government Department of Infrastructure, Transport, Regional Development and Communications, 2021).

\section{Yerel Yönetimler ve İnsan Kaynakları}

Halka en yakın hizmet birimi olan yerel yönetimler, yöre halkının talep ve beklentilerinin karşılanması noktasında önem arz etmektedir. Ayrıca, vatandaşların ihtiyaç ve sorunlarının tespit edilebilmesi ve bu çerçevede gelecek projelere yön verilmesi yerel yönetim kuruluşlarının sorumluluğu altındadır. Sözü edilen süreçlerin sağlıklı şekilde yürütülebilmesi ve başarılı çıktılara 
ulaşılabilmesi için çeşitli politika kaynaklarına gereksinim duyulmaktadır. Personel ya da insan kaynakları, politikaların etkin ve verimli şekilde uygulanabilmesi ve istenilen hedeflerine ulaşılabilmesi açısından işlevsel bir nitelik taşımaktadır (Knoepfel, Larrue, Varone ve Hill, 2007: 66-69). Bu nedenle, yerel düzeydeki politikaların oluşturulması ve hayata geçirilebilmesi personel kaynağı potansiyeliyle doğrudan ilişkilidir. Özellikle, halkla direk etkileşimde olan kamu çalışanları olarak ifade edilen "Sokak Düzeyi Bürokratları" (Lipsky, 1980; 2010) hem yerel hem de ulusal düzey politikaların başarısında büyük rol oynamaktadır. Öyle ki, yerel düzeydeki politikalar halkın talepleri doğrultusunda titizlikle oluşturulsa dahi, sokak düzeyi bürokratların uygulama aşamasındaki bilgisizlik, tecrübesizlik ve özensizliği tüm sürecin başarısızlıkla sonuçlanmasına yol açabilmektedir.

Avustralya yerel yönetim birimleri, stratejik insan kaynakları ve yönetimi anlayışı çerçevesinde personel politikalarına yön vermektedir. Bu sayede, her düzeyde yerel yönetim çalışanlarının iş verimini artırmak amaçlanmaktadır. Öte yandan, yerel yönetim birimlerinin nitelikli personel istihdamını gerçekleştirmesi, bazı dönemlerde piyasa rekabetinin de etkisiyle daha zor olduğu görülmektedir. Dolayısıyla, yerel yönetimlerin kalifiye personele sahip olabilmesi için mevcut ve potansiyel işgücünün ihtiyaç ve taleplerine daha duyarlı olmaları gerekmektedir (Woods, Artist ve O'Connor, 2015: 123).

Avustralya'da yerel yönetimlerde istihdam edilen personel sayısı incelendiğinde, toplam kamu personeli sayısının küçük bir bölümünü oluşturmaktadır. Öyle ki, 2020 yılı itibariyle Avustralya' da 2.041.200 adet kamu personeli görevlerine devam etmektedir. Yerel yönetimlerde ise sadece 186.000 kamu çalışanı görev yapmaktadır (Australian Bureau of Statistics, 2020). Bu bağlamda, kamu personellerinin büyük bir oranda merkezi yönetim teşkilatlarında istihdam edildiği görülmektedir. Avustralya yerel yönetim birimlerinde görev yapan personellerin statüleri incelendiğinde, genellikle tam zamanlı çalışma usulünün benimsenmiş olması dikkat çekmektedir. Çalışanların \%68'inin tam zamanlı, \%16'sının yarı zamanlı ve yine \%16'sının da geçici işçi olarak çalıştığı görülmektedir. Öte yandan, Avustralya'da yerel yönetimlerin \%69'unun özellikle mühendislik, şehir ve bölge planlama, çevre sağlık ve proje yönetimi alanlarında nitelikli personel ihtiyacı sorunu bulunmaktadır. Söz konusu ihtiyacın ortaya çıkması ve devam etmesinin birtakım temel sebepleri bulunmaktadır. Bu sebepler; yerel yönetimlerin personellere sağlanacak özlük hakları konusunda özel sektörle rekabet edemeyecek durumda olması, yerel düzeyde çalıştırılabilecek nitelikli personelin çok az olması ve özellikle bazı meslek dallarında işgücü piyasasında yüksek talep olması şeklinde sıralanabilir. Avustralya yerel yönetim birimlerinde engelli personel istihdamı uygulamasına yer verilmektedir. Ancak, engelli personelin toplam işgücü içerisinde oranı oldukça küçük bir oran olup yaklaş1k \%0,8' dir (Australian Local Government Association, 2018: 6-22). 
Avustralya'da yerel yönetimlerde yürütülen personel ya da insan kaynakları politikası incelendiğinde birtakım politika tavsiyeleri sunmak ya da tespitlerde bulunmak mümkündür. İlk olarak, yerel yönetimlerde görev yapan personel sayısının merkezi yönetime kıyasla oldukça düşük seviyelerde kalması tartışmaya açık bir husustur. Yerel yönetimlerin sunduğu hizmetler, görev tanımları ve iş yükleri göz önünde bulundurularak yeniden bir değerlendirme yapılması gerekmektedir. Böylelikle, personel eksikliği dolayısıyla meydana gelebilecek hizmet aksamalarının önüne geçilebilir ve vatandaş memnuniyeti artırabilir. Yerel yönetimlerde bazı meslek alanlarında personel istihdamı konusunda büyük problemlerin yaşandığı görülmektedir. Yerel yönetimler için hayati önem taşıyan alanlarda personel ihtiyacının giderilebilmesi için bazı düzenlemelerin yapılması gerekmektedir. Örneğin, mühendislik, şehir ve bölge planlama ve çevre sağlığı gibi alanlardaki personel eksikliğinin giderilebilmesi için çalışma koşullarının ve imkânlarının en üst seviyelere çıkarılması önemli bir adım olabilir. Bu çerçevede, bahsedilen alanlardaki uzman personel için yerel yönetim birimlerinde görev almak daha cazip hale gelebilir. Buna ek olarak, Avustralya yerel yönetim birimlerinde görev yapan mevcut personelin niteliklerinin geliştirilebilmesi için eğitim programlarının daha sı düzenlenmesi önem taşımaktadır. Hizmet öncesi ve hizmet içi eğitimler vasıtasıyla çalışanların çeşitli alanlarda uzmanlaşmalarına destek olunabilir. Böylece, yerel yönetimler tarafından sunulan hizmetlerin kalitesinde kayda değer değişimler yaşanması sağlanabilir.

\section{Yerel Yönetimlerde Katılım}

Avustralya, 19 ve 20. Yüzyıllarda demokratik kurumlara sahip olmanın yanı sıra medeni ve siyasal hakların artırılabilmesi adına önemli mücadelelerin verildiği ülkelerden birisidir. Bu doğrultuda, azınlık haklarının korunması, hukuk üstünlügünün desteklenmesi ve vatandaş katılımının teşvik edilmesi amacıyla Avustralya'da çeşitli reformlar hayata geçirilmiştir (Head, 2011: 103). Yapılan reformlar ile özellikle sivil katılım noktasında gösterilen çabaların daha somut çıtılara dönüştürülmesi hedeflenmiştir. Yerel yönetimlerin her ne kadar yetki düzeyleri sınırlı olsa da kütüphaneler ve toplum merkezleri, şehir planlaması, yerel ulaşım ve çöp toplama gibi birçok günlük hizmet ve tesislerden sorumlu oldukları (Freeman, 2016: 200) ifade edilmektedir. Sözü edilen sorumlulukların önemli bir kısmını da vatandaşların yerel düzeydeki sorunlarının belirlenmesi oluşturmaktadır. $\mathrm{Bu}$ nedenle, vatandaşların yerel düzeydeki problemlerinin tespit ve çözüm süreçlerine katılımı sonucu oluşan faydalar (Head, 2007: 443), yerel yönetim birimlerinin hizmet etkinliği ve verimliliğine yansımaktadır. Vatandaşların farklı politika alanlarında yaşadıkları olumsuzluklar daha ivedi şekilde ortadan kaldırılmakta ve yerel yönetimler vatandaş katılımı sayesinde çeşitli politika alternatiflerine sahip olma fırsatı elde etmektedir. 
Avustralya yerel yönetim birimlerinin faaliyetleri incelendiğinde, sivil katılımı artırmaya yönelik politikaların izlendiği görülmektedir. Öyle ki, yerel yönetimlerin vatandaşları hizmet kullanıcısı ya da müşteri olarak görmek yerine, onlarla daha yakın ilişkiler kurmaya eğilimli oldukları ve bu doğrultuda protokollerin geliştirilerek yüksek düzeyde istişarelere önem verdikleri (Aulich, 2009: 57) belirtilmektedir. Sivil katılımın sağlanması ve geliştirilmesi hususunda çeşitli teknikler ve süreçler bulunmaktadır. Head (2007: 443-444) sözü edilen süreçte kullanılan teknikleri; grup ve kamuoyu anketleri düzenlemek, gruplara bilgi aktarımı sağlamak, öne çıkan isimlere danışmak, forum ve danışma kurulları oluşturmak ve topluluk organlarına finansal destek sunmak gibi sıralamaktadır. Toplumdaki problemlere ilişkin politika ya da danışma kurullarının oluşturulması, yerel yönetimlerin sivil katılıma yönelik tutumunu göstermektedir (Babaoğlu, 2013; Babaoğlu ve Babaoğlu, 2020: 200). Bu doğrultuda, Avustralya'da vatandaş katılımının etkili şekilde tesis edildiği ve buna ilişkin de örneklerin yer aldığ (Aulich, 2009: 57) ifade edilmektedir. Avustralya'da yerel yönetimlerde halk katılımının hayata geçirilebilmesi için eyaletler bazında farklı uygulamalara gidilmektedir. Eyaletler arasında yerel yönetim ve katılım konularına ilişkin birtakım benzerlikler görülse de yasal düzenlemeler, çeşitli uygulamalar, master ve yerel alan planlamaları çerçevesinde farklılaşmalar yer almaktadır (Grant, Dollery ve Kortt, 2011). Avustralya yerel yönetim birimlerinde, uygulamada ve mevzuatta görülen farklılaşmaların sivil katılım düzeyine doğrudan etki etmektedir. Diğer bir ifadeyle, dijitalleşme, sosyal medya kullanımı, bütçeleme ve en önemlisi yönetişim gibi kavramların eyaletler düzeyindeki yansımaları farklılaşabilmektedir.

Dijitalleşme, özel sektördeki olduğu gibi kamu sektöründe de özellikle son 20 yılda önemli bir ivme yakalamıştır. Yerel yönetim birimleri tarafindan sunulan hizmetler, geliştirilen uygulamalar ile desteklenerek vatandaşların daha iyi hizmet almaları sağlanmaktadır (Karasoy ve Babaoğlu, 2020: 116). Dünya'nın ilk dijital belediyesi olarak bilinen Hollanda'nın Molenwaard Belediyesi örneğinde de olduğu gibi yerel hizmetlerin belediye binası bile olmadan sadece dijital belediyecilik uygulamaları ile sunulması (Erdoğan, 2019: 72), gelecek dönemlerde karşılaşacağımız dijital dönüşüm için ciddi ipuçları vermektedir. Ayrıca, yerel politikaların şekillendirilmesi sürecinde de dijital demokrasi uygulamalarının ön plana çıkmakta ve örneğin Başakşehir Belediyesi'nin yaşayan laboratuvar uygulamasıyla veya Türkiye'nin ilk dijital demokrasi platformu olan Muratpaşa Belediyesi Komşu Meclis Uygulaması sayesinde vatandaşlar karar alma süreçlerine doğrudan katılım sağlayabilmektedirler (Babaoğlu ve Memiş, 2020: 202; Erdoğan, 2020: 54).

Avustralya yerel yönetimlerinde de dijitalleşmeye olan talebin ve hayata geçirilen uygulamaların giderek arttığını söylemek mümkündür. Yerel yönetim birimlerinin faydalandığı uygulamalar incelendiğinde, sivil katılım için özellikle sosyal medya önem kazanmaktadır. Ancak 
kırsal kesimlerde hizmet sunan yerel yönetim birimlerinin, vatandaşlarla ile iletişimde sosyal medyayı kullanmak ve bu süreci yönetmek için yeterli kaynağa sahip değildirler. Sözü edilen yerel yönetimler, sınırlı bağlantıları ve kaynakları dolayısıyla sivil katılımı sağlamak için gerekli olan sosyal medya ve dijital platformlardan yararlanma hususunda ciddi bir dezavantaj yaşamaktadırlar (Freeman, 2016: 202-214). Dijitalleşme ve katılım bağlamında yeterli altyapı ve donanıma sahip yerel yönetim kuruluşlarının, vatandaş taleplerine sosyal medya platformları vasıtasıyla daha duyarlı olmakta ve eylem kapasiteleri genişlemektedir (Babaoğlu ve Akman, 2018: 79). Avustralya federal politikaları da incelendiğinde, yerel düzeyde dijital devlet anlayışının benimsendiği görülmektedir. Öyle ki, Ulusal Dijital Ekonomi Stratejisi ve benzer politikalar ile yerel yönetimlerde dijitalleşme ve katılım konularına önem verilmektedir (Department of Broadband and Communications and the Digital Economy (DBCDE), 2011). Bu sayede vatandaşlar, yerel yönetim düzeyinde çeşitli konuların tartışıldığı ve karar alma süreçlerinin yaşandığı platformlarda yer almaktadır (Serrao-Neumann, Harman, Leitch ve Low Choy, 2015).

Yerel yönetimlerde, bütçeyle ilgili konular genellikle ön plana çıkmaktadır. Yerel politikaların sorunsuz şekilde yürürlüğe konulabilmesi ve vatandaşların taleplerine daha duyarlı olunabilmesi için bütçe önem arz etmektedir. Hatta, para ya da finansal kaynaklar, kamu politikasının en önemli kaynakları arasında sıralanmaktadır (Knoepfel ve diğerleri., 2007: 69). Avustralya'da da yerel yönetimlerde bütçeleme konularında vatandaşlarının katılımını destekleyen ve teşvik eden faaliyetler yer almaktadır. Avustralya yerel yönetimlerinde, özellikle katılımcı bütçeleme uygulamalarıyla sivil katılım tesis edilmektedir (Thompson, 2012). Bu bağlamda, etkin yönetişim, meşruiyet ve adalet gibi ilkelerin benimsenebilmesi için katılımcı bütçelemenin Avustralya yerel yönetim birimlerinde devam etmesi ve artması önem taşımaktadır (Christensen ve Grant, 2016: 470).

\section{Sonuç}

Avustralya'da federal, eyalet veya bölge ve yerel düzey olarak üç hükümet düzeyi mevcut bulunmaktadır (European Parliament, 2020: 1). Ülke; Avustralya'nın devlet başkanı olarak Kraliçe II. Elizabeth ile ülke anayasal bir monarşi ve aynı zamanda temsili bir demokrasi olmakla birlikte, hükümetin üç kolu yasama organı ya da parlamento, yürütme (Avustralya Hükümeti) ve yargıdan oluşmaktadır (Australian Government, 2021). Avustralya'da yerel yönetimler eyalet Anayasaları kapsamında ve Kuzey Bölgesi’nin Anayasası olan federal mevzuat kapsamında tanınırlığı söz konusu bulunmakta ve her bölge ya da eyalet yerel yönetim mevzuatına sahip durumda olmaktadır (CLGF, 2017-2018: 5). 1995 tarihli Yerel Yönetim Yasas1 yerel yönetimlerin işlevleri, yerel yönetimlerin işlerinin incelenmesi, seçimlerin nasıl gerçekleşmesi gerektiği gibi konuları açıklamaktadır (Government of Western Australia, 2019: 2). Ayrıca, 1995 
tarihli Yerel Yönetimler Yasas1, yerel yönetimler ve yerel yönetim meclisleri, meclisin rolü, belediye başkanı veya başkanın rolü, meclis üyelerinin rolü başlıklarına sahip maddeleri çerçevesinde yerel yönetimlere idari organları ve görevlerine ilişkin önemli ifadeleri barındırmaktadır (Western Australia Local Government Act, 1995).

Avustralya yerel yönetimlerinin gelir durumu değerlendirilecek olunursa, yerel yönetimler kendi gelirlerinde harçlar, ücretler ve tek vergi geliri olan oranlar vasıtasıyla artış sağlamakta ve Avustralya Hükümeti tarafından sağlanan finansman önem arz etmektedir (Australian Local Government Association, 2021b: 1). Avustralya yönetsel sistemi içerisinde yerel yönetimlerin etkin ve kaliteli yerel hizmet sunumu gerçekleştirebilmeleri yeterli gelir kaynaklarının mevcudiyetine bağlı bulunmaktadır; bu kapsamda, Avustralya Hükümetince sağlanan finansman desteği yerel yönetimlerin hizmet sunumu açısından kritik öneme sahiptir.

Avustralya yerel yönetim birimlerinde nitelikli işgücü istihdamının daha kolay ve mümkün olabilmesi için çeşitli düzenlemelerin hayata geçirilmesi gerekmektedir. Böylelikle, yerel yönetimler politika oluşturma ve uygulama aşamalarında nitelikli personel altyapısı sayesinde daha başarılı sonuçlar elde edebilmektedir. Öte yandan, engelli politikası ülkelerin uyguladıkları en önemli politikaların başında yer almaktadır. Avustralya yerel yönetim birimlerde görev yapan engelli birey sayısının oldukça düşük olmasından dolayı yeni yasal düzenlemelerin yapılması gerekmektedir. Engelli vatandaşların özellikle yerel yönetimlerde daha fazla istihdamı, başta sosyal politikalar olmak üzere çeşitli politika alanlarına da olumlu katkılar sunabilmektedir. Sivil katılım düzeyinin daha iyi seviyelere getirilmesi ve başta mali politikalar olmak üzere birçok kamu politika alanındaki faaliyetlerde halk katılımına önem verilmesi ümitvari bir çerçeve sunmaktadır. Avustralya yerel yönetimlerine ilişkin kapsamlı çalışmaların yapılması ülke yerel yönetim incelemelerine dair akademik literatüre katkı sağlayacaktır.

Yazar katkıları: Zuhal Önez Çetin ve Onur Kulaç çalışmanın tüm bölümlerinde ve aşamalarında katkı sağlamışlardır. Yazarlar esere eşit oranda katkı sunmuştur.

Çıkar beyanı: Yazarlar ya da herhangi bir kurum/kuruluş arasında çıkar çatışması yoktur.

Teşekkür: Yayın sürecinde katkısı olan hakemler ile editör kuruluna teşekkür ederiz.

\section{Kaynakça}

Aulich, C. (2009). From Citizen Participation to Participatory Governance in Australian Local Government, Commonwealth Journal of Local Governance, (2), 44-60.

Australian Bureau of Statistics (2020, Aral1k). Employment and Earnings, Public Sector, Australia. Erişim Adresi: https://www.abs.gov.au/ statistics/ labour /employment-andunemployment/employment-and-earnings-public-sector-australia/latest- 
release\#: :text=Key\%20statistics,-There\%2 2 0were\%202 $\% \quad$ 2C $041 \% 2 \mathrm{C} 200 \&$ text $=246 \% 2 \mathrm{C} 000 \% 20 \mathrm{employees} \% 20 \mathrm{in} \% 20 \mathrm{Commonwealth} \% \quad 20 \mathrm{go}$ vernment, $186 \% 2$ C000\%20in\%20local\% 20government.

Australian Embassy (2021, 8 Ocak). Tell Me about Australia. Australian Embassy. Erişim Adresi: https://turkey.embassy.gov.au/files/anka/TellMeAboutAustral ia.pdf

Australian Government (2014-2015). Australian Government Department of Infrastructure and Regional Development Local Government National Report, 2014-2015. Erişim Adresi: https://www.regional.gov.au/local/publications/ 2014_2015/LGN_REPORT_2014-15.pdf

reports/

Australian Government (2021, 8 Ocak). Australia.gov.au., How Government Works, Erişim Adresi: https://info.australia.gov.au/about-government/how-governm ent-works

Australian Government Australian Trade Commission (2016). Introduction to the Levels of Government in Australia, Implications for Investors. Australian Government, Australian Trade Commission Publication.

Australian Government Department of Foreign Affairs and Trade (2016). Australia in Brief, Australian Government, Department of Foreign Affairs and Trade Publication.

Australian Government Department of Infrastructure, Transport, Regional Development and Communications (2021, Ocak). Financial Assistance Grant to Local Government. Erişim Adresi: https://www.regional.gov.au/local/assistance/ index.aspx

Australian Government Department of Infrastructure, Transport, Regional Development and Local Government (2007-2008). Local Government National Report 2007-2008. Erişim Adresi: https://www.regional.gov.au/local/publications/pdf/lgnr_2007-08.pdf

Australian Government Productivity Commission (2017). Shifting The Dial, 5 Year Productivity Review, Supporting Paper No.16, Local Government. Australian Government, Productivity Commission.

Australian Local Government Association (2018). Local Government Workforce and Future Skills Report Australia.

Australian Local Government Association (2021a). Fact Sheet 2: Local Government and The Community. Australian Local Government Association Publication.

Australian Local Government Association (2021b). Fact Sheet 5: Local Government, The Constitution and Funding. Australian Local Government Association Publication.

Australian Local Government Association (2021c, Ocak). Facts and figures: local government key facts and figures. Erişim Adresi: https://alga.asn.au/facts-and-figures/

Avustralya Ülke Bülteni (2018, Ocak). Erişim Adresi: http://www.mto.org.tr/uploads /mto/contentFile_702_241255bec2b41610ad.pdf

Babaoğlu, C. ve Memiş, L. (2020). Laboratuvardan Yerele: Yaşayan Laboratuvarlar ve Yerel Politika. M. Yıldız ve C. Babaoğlu (Ed.), Teknoloji ve Kamu Politikaları kitabı içinde (s. 199-232). Ankara: Gazi Kitabevi.

Babaoğlu, C. ve Babaoğlu, P. (2020). Engelli Ombudsmanlı̆̆ı. O. Erdoğan (Ed.), Ombudsmanlık kitabı içinde (s. 185-206). Ankara: Nobel.

Babaoğlu, C. ve Akman, E. (2018). Local Participation with Facebook: The Case of Turkey. L. A. Munoz (Ed.), Optimizing e-Participation Initiatives through Social Media kitabı içinde (s. 77-95). Hersey/PA: IGI Global. 
Babaoğlu, C. (2013). Kamu Politikaları Sürecinde Sivil Toplum Kuruluşlarının Rolü. M. Yıldız ve M. Z. Sobacı (Ed.), Kamu Politikaları: Kuram ve Uygulama kitabı içinde (s. 166187). Ankara: Adres Yayınları.

Christensen, H. E. ve Grant, B. (2016). Participatory Budgeting in Australian Local Government: An Initial Assessment and Critical Issues, Australian Journal of Public Administration, 75(4), 457-475.

CLGF (2017-2018). Country Profile 2017-2018, The Local Government System in Australia, Commonwealth Local Government Forum, Erişim Adresi: http://www.clgf.org. uk/ default/assets/File/Country_profiles/Australia.pdf

Commonwealth of Australia (2010). Australia's Constitution: With Overview and Notes by the Australian Government Solicitor. Commonwealth of Australia.

Constitutional Centre of Western Australia (2019). Constitutional center-what is parliament. Western Australia Publication. Erişim Adresi: https://www.wa. Gov.au/sites/default/files/201909/The\%20Three\%20Arms\%20of\%20Government$\% 20$ Constitutional\%20Centre\%20of\%20Western\%20Au stralia $\% 20$ pdf.

Department of Broadband, Communications and the Digital Economy (DBCDE) (2011). National Digital Economy Strategy: Leveraging the National Broadband Network to Drive Australia's Digital Productivity. Canberra, ACT: DBCDE.

Department of Local Government, Sport and Cultural Industries (2021a, Ocak). Local laws. Erişim Adresi: https://www.dlgsc.wa.gov.au/local-government/localgovernments/local-laws

Department of Local Government, Sport and Cultural Industries (2021b, Ocak). An introduction to local government, Erişim Adresi: https:/www.dlgsc.wa.gov.au/ localgovernment/local-governments/council-elections/an-introduction-to-local-government

Dış Ekonomik İlişkiler Kurulu/DEIK (2014). Avustralya Ülke Bülteni Şubat 2014. Dış Ekonomik İlişkiler Kurulu.

Erdoğan, O. (2019). Yerel Yönetimlerde Dijital Dönüşüm: Molenwaard Belediyesi Örneği, Siirt Üniversitesi Sosyal Bilimler Enstitüsü Dergisi, 7(13), 59-74.

Erdoğan, O. (2020). Yerel Politikaların Şekillenmesinde Dijital Demokrasi Uygulaması Olarak Antalya Muratpaşa Belediyesi Komşu Meclisi, Uluslararası Yönetim Akademisi Dergisi, 3(1), 48-60.

European Parliament (2020). Briefing Continental Democracies: Government System and Institutions of Australia. European Parliament Publication. Erişim Adresi: https://www.europarl.europa.eu/RegData/etudes/BRIE/2020/646187/EPRS_BRI(2020 646187_EN.pdf

Freeman, J. (2016). Digital Civic Participation in Australian Local Governments: Everyday Practices and Opportunities for Engagement. M. Z. Sobac1 (Ed.), Social Media and Local Governments: Theory and Practice kitabı içinde (s. 195-218). Switzerland: Springer.

Government of Western Australia (2019). An Introduction to Local Government, 2019 Local Elections-Fact Sheet 1. Department of Local Government, Sport and Cultural Industries Publication.

Grant, B., Dollery, B. E. ve Kortt, M. (2011). Australian Local Government and Community Engagement: Are All Our Community Engagement Plans the Same? Does it Matter. Centre for Local Government Working Paper Series. 
Head, B. W. (2007). Community Engagement: Participation on Whose Terms?, Australian Journal of Political Science, 42(3), 441-454.

Head, B. W. (2011). Australian Experience: Civic Engagement as Symbol and Substance, Public Administration and Development, 31(2), 102-112.

Karasoy, A. ve Babaoğlu, P. (2020). Türkiye'de Elektronik Devletten Dijital Devlete Doğru, Karadeniz Sosyal Bilimler Dergisi, 12(23), 115-134.

Knoepfel, P., Larrue, C., Varone, F. ve Hill, M. (2007). Public Policy Analysis, Bristol: The Policy Press.

Library of Congress (2005). Country Profile Australia, 2005. Library of Congress-Federal Research Division, September 2005, Erişim Adresi: https://www.loc.gov/rr/frd/ cs/profiles/ Australia.pdf.

Lipsky, M. (1980). Street-Level Bureaucracy: Dilemmas of the Individual in Public Service, New York: Russell Sage Foundation.

Lipsky, M. (2010). Street-Level Bureaucracy: Dilemmas of the Individual in Public Service. 30th Anniversary Expanded Ed., New York: Russell Sage Foundation.

Parliament of Australia (2021a, Ocak). Parliament and Government. Erişim Adresi: https://www.aph.gov.au/About_Parliament/Work_of_the_Parliament/Forming _and_Governing_a_Nation/parl\#govgen

Parliament of Australia (2021b, Ocak). Work of Parliament. Erişim Adresi: https://www.aph.gov.au/about_parliament/work_of_the_parliament

Parliament of Australia House of Representatives (2019). Infosheet 20 - The Australian system of government, November 2019.

Parliament of Australia House of Representatives (2020). InfoSheet 19, The House, Government and Opposition, August 2020.

Parliament of New South Wales (2021). Levels of Government in Australia, Parliament of New South Wales Publication. Erişim Adresi: https:// www.parliament.nsw.gov.au/about/education/Documents/classroom-activity-2-levelsof-government-in-aus/Classroom\%20Activity\%202\%20Levels\%20 of \% 20Government\%20in\%20 Australia.pdf

Parliamentary Education Office (2021a, Ocak). Australian Constitution. Erişim Adresi: https://peo.gov.au/understand-our-parliament/how-parliament-works/the-australianconstitution/australian-constitution/

Parliamentary Education Office (2021b, Ocak). Introducing Australia's System of Government. Erişim Adresi: https://peo.gov.au/understand-our-parliament/how-parliamentworks/system-of-government/introducing-system-of-government/

Parliamentary Education Office (2021c, Ocak). The roles and responsibilities of the three levels of government. Erişim Adresi: https://peo.gov.au/understand-our-parliament/howparliament-works/three-levels-of-government/the-roles-and-responsibilities-of-thethree-levels-of-government/

Parliamentary Education Office (2021d, Ocak). Cabinet, Erişim Adresi: https:// peo.gov.au/understand-our-parliament/parliament-and-its-people/government/cabinet/

Serrao-Neumann, S., Harman, B., Leitch, A. ve LowChoy, D. (2015). Public Engagement and Climate Adaptation: Insights from Three Local Governments in Australia, Journal of Environmental Planning and Management, 58(7), 1196-1216. 
The Commonwealth (2021). Australia: History. Erişim Adresi: https://thecommon wealth.org/our-member-countries/australia/history

Thompson, N. K. (2012). Participatory Budgeting-the Australian Way, Journal of Public Deliberation, 8(2), 1-15.

Western Australia Local Government Act (1995). Western Australia Local Government Act. Erişim Adresi: https://www.legislation.wa.gov.au/legislation/ statutes.nsf/ main_mrtitle_551_homepage.html

Woods, R., Artist, S. ve O'Connor, G. (2015). Learning in Australian Local Government: A Roadmap for Improving Education \& Training, Commonwealth Journal of Local Governance, 18, 108-126.

Yılmaz, N. (2021). Avustralya'da Yerel Yönetimlerin İdari ve Mali Yapısı. Ç. Akman ve İ. A. Acar (Ed.), Dünya'da Yerel Yönetimler ve Mali Yapıları kitabı içinde (s. 85-116), Ankara: Nobel Yayınevi. 